\title{
Thermal Properties of WC-10 wt. (\%) Co Alloys
}

\section{Francisco de Assis Léo Machado ${ }^{\mathrm{a} *}$, Márcio Ferreira Rodrigues ${ }^{\mathrm{b}}$, Helion Vargas $^{\mathrm{a}}$,}

\author{
Marcello Filgueira ${ }^{\mathrm{b}}$, Roberto da Trindade Faria Júnior ${ }^{\mathrm{a}}$
}

a'Laboratório de Ciências Físicas

b Programa de Pós-Graduação em Engenharia e Ciências dos Materiais, Universidade Estadual do Norte Fluminense Darcy Ribeiro - UENF, Av. Alberto Lamego, 2000

Pq. Califórnia Campos dos Goytacazes-RJ, Brazil

Received: March 23, 2007; Revised: February 29, 2008

\begin{abstract}
In this article, photothermal techniques were used in order to determine some thermal properties: diffusivity, conductivity, effusivity and specific heat capacity of WC-10 wt. (\%) Co six samples subjected to different sintering processes. The samples were sintered using high pressure - high temperature (HPHT) sintering system. The open cell photoacoustic (OPC) used to measure thermal diffusivity is described in detail. The values of thermal properties here measured and evaluated are consistent to those previously reported in the literature.
\end{abstract}

Keywords: hardmetal, photothermal techniques, thermal characterization

\section{Introduction}

Since the discovery of the photoacoustic effect by Bell in $1881^{1}$, the so-called photoacoustic techniques have experienced great expansion. Nowadays, they are used in a wide range of scientific areas. The photoacoustic and related photothermal techniques have proved to be a valuable tool to thermal characterization of solids, liquids and gases $^{2}$. This is one of the non-destructive laser-induced photothermal techniques that are based on the detection of periodic thermal waves generated due to a non-radiative de-excitation in the sample, which is illuminated by a chopped or pulsed optical excitation. In this paper, thermal and structural characteristics of hardmetal (WC-10 wt. (\%) Co) alloys was examined.

The WC-Co is one of the most common hardmetals. It is a liquidphase sintered powder metallurgical that consists of very refractory carbides embedded in a tough metal binder ${ }^{3}$. Hardmetal WC-Co is widely used in oil and metallurgic industries, in particular, in extensively applications that demanding wear resistance (e.g. cutting tools, drilling and mining equipments, wire-drawing or metal-forming dies) due to the high stability and excellent mechanical properties. Thermal characterization plays an important role to qualify hardmetals. Rare are the literatures that analyze these properties ${ }^{4,5}$. The present article intends to discuss the thermal behavior in six diversified WC-10 wt. (\%) Co samples (Table 1), which are sintered in a not-conventional route metallurgic powder named high pressure-high temperature (HPHT), normally used to produce synthetic diamonds. For more details of HPHT see references ${ }^{6,7}$.

The quantity that measures the rate of heat diffusion into a material is the thermal diffusivity $(\alpha)$. This property depends closely on the microstructural variations, composition and the processing conditions of the sample ${ }^{8}$. Equation 1 presents the relationship among the thermal properties. In this case, thermal diffusivity and thermal effusivity (e) are defined as in function of thermal conductivity ( $\mathrm{k}$ ) and specific thermal capacity $(\mathrm{C}), \mathrm{C}=\rho \mathrm{c}$, where $\mathrm{c}$ is the specific heat and $\rho$ is the mass density.

$$
\alpha=\frac{\mathrm{k}}{\mathrm{C}} \quad \mathrm{e}=\sqrt{\mathrm{kC}}
$$

The thermal effusivity measures essentially, the thermal impedance of the sample, i.e., the sample's ability to exchange heat with environment ${ }^{9}$.

In the present investigation, an open photoacoustic cell (OPC) in the transmission configuration ${ }^{2,10,11}$ is employed to evaluate thermal diffusivity and the photothermal technique of continuous investigation illumination on the sample in a vacuum ${ }^{12}$ is used to measure thermal capacity density.

\section{Experimental}

\subsection{Samples}

WC and Co Commercial powders (of mean particle size of $5 \mu \mathrm{m}$ both) were purchased from Derivate Ind. Com. These powders were manually mixed to perform the stoichiometry WC-10 wt. (\%) Co. The theoretical density of this hardmetal is $14.7 \% \mathrm{~g} . \mathrm{cm}^{-3}$. Mixture was divided in samples of about $1 \mathrm{~g}$ each. Samples were inserted in a graphite cylinder that acts as a heater (due to a current flux that runs through the cylinder during pressing) and then assembled into a calcite capsule responsible for the gasket formation, which ensures a good high pressure distribution into the material. Sintering treatments were carried out using a special hot press (by RyazantyashpressmashO138B type $2500 \mathrm{t}$ ). Table 1 shows the sintering parameters of WC-10 wt. (\%) samples produced by HPHT.

\subsection{Photoacoustic investigation - measurement of thermal diffusivity}

The OPC technique is widely used for several applications aiming at the thermal characterization of great variety of samples such as wood $^{13}$, two layer systems ${ }^{14}$, semiconductors ${ }^{15}$, polymers ${ }^{16}$, clays ${ }^{17}$, and so on. The schematic cross section of the OPC configuration is show in Figure 1. In this configuration the solid sample is mounted directly on of top of an electrets microphone, leaving a small volume of air in between the sample and the microphone. The sample is irradiated on front surface by modulated light. After absorption, it is converted into heat through the light non-radiative de-excitation. The 
Table 1. Parameters sintering of samples WC-10 wt. (\%) Co sintered by HPHT.

\begin{tabular}{cc}
\hline Number of samples & Pressure/Temperature/Time \\
\hline 1 & $5 \mathrm{GPa} / 1200{ }^{\circ} \mathrm{C} / 1$ minute \\
1 & $5 \mathrm{GPa} / 1300{ }^{\circ} \mathrm{C} / 1$ minute \\
1 & $5 \mathrm{GPa} / 1400{ }^{\circ} \mathrm{C} / 1$ minute \\
1 & $5 \mathrm{GPa} / 1200{ }^{\circ} \mathrm{C} / 2$ minutes \\
1 & $5 \mathrm{GPa} / 1300{ }^{\circ} \mathrm{C} / 2$ minutes \\
1 & $5 \mathrm{GPa} / 1400{ }^{\circ} \mathrm{C} / 2$ minutes \\
\hline
\end{tabular}

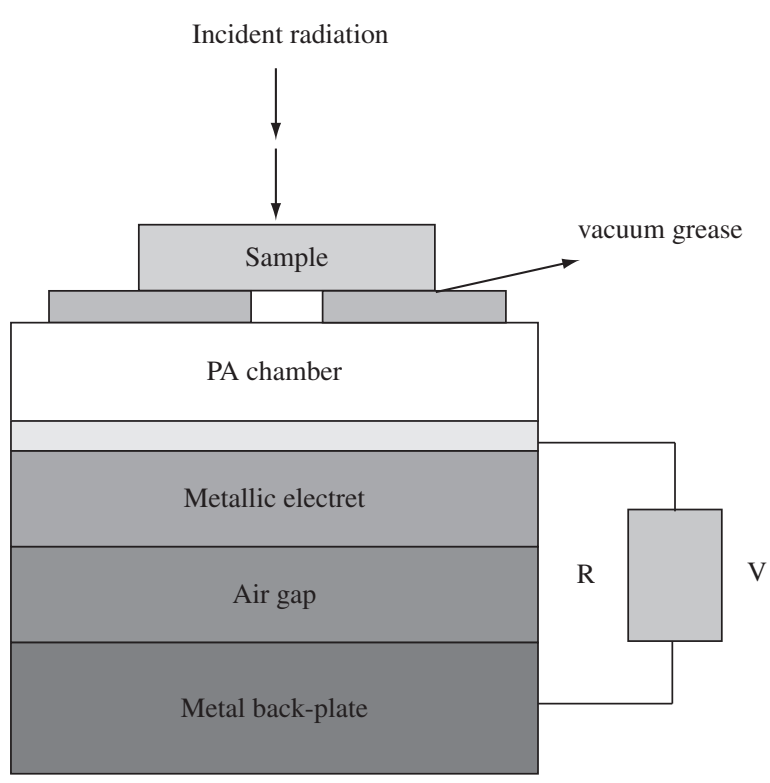

Figure 1. Open Photoacoustic Cell (OPC).

pressure fluctuations in the gas produced by the periodic heat flow can be detected as acoustic wave signals by the microphone.

In this study we have used a He-Ne laser $(25 \mathrm{~mW})$ as the excitation source. The disc sample WC-10 wt. (\%) Co is mounted in the top of air chamber using vacuum grease and is illuminated on its surface facing the ambient. The laser beam modulation is produced by a mechanical chopper (Stanford Research Systems SR540). The resulting PA signal is then subsequently fed into a field-effecttransistor (FET) pre-amplifier and leads directly to a "Lock-in" amplifier (Perkin Elmer Instruments mod. 5210), where it is possible to obtain the photoacoustic amplitude and the phase signal, which are recorded as a function of the modulation frequency in an appropriate software program.

Applying the simple one-dimensional thermal diffusion model of Rosencwaig and Gersho ${ }^{18}$, the expression for the pressure fluctuation $(\delta \mathrm{P})$ in the air chamber is

$$
\delta P=\frac{\gamma \mathrm{I}_{0}\left(\alpha_{\mathrm{g}} \alpha_{\mathrm{s}}\right)^{1 / 2}}{2 \pi \mathrm{l}_{\mathrm{g}} \mathrm{T}_{0} \mathrm{k}_{\mathrm{s}} \mathrm{f}} \frac{\mathrm{e}^{\mathrm{j}\left(\omega \mathrm{t}-\frac{\pi}{2}\right)}}{\operatorname{senh}\left(\sigma_{\mathrm{s}} \mathrm{l}_{\mathrm{s}}\right)},
$$

where $\gamma$ is the air specific heat ratio, $\mathrm{P}_{0}$ the ambient pressure, $\mathrm{T}_{0}$ ambient temperature, $\mathrm{I}_{0}$ is the absorved light intensity, $\mathrm{f}$ is the modulation frequency, and $\mathrm{l}_{\mathrm{i}}, \mathrm{k}_{\mathrm{i}}$, and $\alpha_{\mathrm{i}}$ are the length, thermal conductivity and the thermal diffusivity of the sample respectively. Here $i=s$ subscript denotes sample and $g$ denotes gas medium. Also $\sigma_{\mathrm{s}}=(1+\mathrm{j}) \mathrm{a}_{\mathrm{s}}$ where $a_{s}=\left(\omega / 2 \alpha_{s}\right)^{1 / 2}$ is the material complex thermal diffusion coefficient of the material.

If the sample is thermally thin (i.e., $\mathrm{l}_{\mathrm{s}} \mathrm{a}_{\mathrm{s}}<<1$ ), Equation 2 reduces to

$$
\delta \mathrm{P}=\frac{\gamma \mathrm{P}_{0} \mathrm{I}_{0}\left(\alpha_{\mathrm{g}} \alpha_{\mathrm{s}}\right)^{1 / 2}}{(2 \pi)^{3 / 2} 1_{\mathrm{g}} \mathrm{l}_{\mathrm{s}} \mathrm{T}_{0} \mathrm{k}_{\mathrm{s}}} \mathrm{e}^{\mathrm{j}\left(\omega \mathrm{t}-3 \frac{\pi}{4}\right)} \frac{1}{\mathrm{f}^{3 / 2}}
$$

That is, the amplitude of the PA signal decreases as $\mathrm{f}^{-1,5}$ as one increases the modulation frequency. In contrast, at high modulation frequencies, such that the sample is thermally thick (i.e. $1_{\mathrm{s}} \mathrm{a}_{\mathrm{s}}>1$ ), then

$$
\delta P=\frac{\gamma P_{0} I_{0}\left(\alpha_{g} \alpha_{s}\right)^{1 / 2}}{\pi l_{g} T_{0} k_{s}} e^{j\left(\omega t-\frac{\pi}{2} 1_{s} a_{s}\right)} \frac{e^{-l_{s}} \sqrt{\frac{\pi f}{\alpha_{s}}}}{f}
$$

Equation 4 means that, for a thermally thick sample, the amplitude of the PA signal decreases exponentially with the modulation frequency as $(1 / \mathrm{f}) \exp (-\mathrm{a} \sqrt{\mathrm{f}})$, where $\mathrm{a}_{\mathrm{s}}=1_{\mathrm{s}} \sqrt{\pi / \alpha_{\mathrm{s}}}$. In this case, $\alpha$ is obtained from the experimental data fitting from the coefficient (a) in the argument of the exponential $(-\mathrm{a} \sqrt{\mathrm{f}})$.

\subsection{Measurement of specific heat capacity}

The product of density and specific heat, $\rho c$, was measured using, the photothermal technique of temperature evolution induced by continuous illumination of the sample in vacuum. The surface sample is painted black and placed inside a Dewar that is subsequently vacuum-sealed. The front surface of the sample is illuminated with the He-Ne laser focused on the sample through an optical glass window on the Dewar. The back surface of the sample has a thin-wire T-type thermocouple. The thermocouple output is measured as in function of time by using a thermocouple monitor (Hewllet Packard 34401 ${ }^{\mathrm{a}}$ Multimeter) connected to a computer. The temperature evolution is monitored up to reach a stationary state. Subsequently, we turn off the laser and the temperature decrease is monitored, as well. Equations 5 (temperature increase) and 6 (temperature decrease) represent these temperature variations,

$$
\begin{aligned}
& \Delta \mathrm{T} \uparrow=\frac{\mathrm{I}_{0}}{\mathrm{H}}\left(1-\mathrm{e}^{-\mathrm{t} / \tau}\right) \\
& \Delta \mathrm{T} \downarrow=\frac{\mathrm{I}_{0}}{\mathrm{H}} \mathrm{e}^{-\mathrm{t} / \tau}
\end{aligned}
$$

\section{Results and Discussion}

We show in Figure 2 the XRD spectra recorded for samples HPHT sintered hardmetal samples. One can observe that there is practically no difference among the samples, only WC/Co peaks are observed and the $\mathrm{Co}_{3} \mathrm{~W}$ phase in presented in all the samples. The Rietveld analysis confirmed the $\mathrm{Co}_{3} \mathrm{~W}$ phase in low intensity for the whole samples. Figure 3 shows the Rietveld analysis for $5 \mathrm{GPa} / 1200{ }^{\circ} \mathrm{C} / 1$ minute sample. This sample has $83,7 \% \mathrm{WC}$ and $6.3 \% \mathrm{Co}_{3} \mathrm{~W}$.

Table 2 shows the whole thermal properties reached, using our alternative method. One can see in Figure 4 a typical curve for thermal diffusivity measurements for the sample subjected to $5 \mathrm{GPa} / 1400{ }^{\circ} \mathrm{C} / 2$ minutes sintering conditions. It was observed that thermal diffusivity values are; in close agreement with previous works by Miranzo et al. ${ }^{19}$ and Lauwers et al. ${ }^{20}$. However, the values obtained for thermal conductivity are lower when compared with other papers ${ }^{5,19}$. 
Table 2. Thermal properties of WC-10 wt. (\%) Co sintered by HPHT.

\begin{tabular}{ccccc}
\hline Samples & $\alpha\left(\mathrm{cm}^{2} / \mathrm{s}\right)$ & $\mathrm{C}\left(\mathrm{J} /\left(\mathrm{cm}^{3} \cdot \mathrm{K}\right)\right)$ & $\mathrm{k}(\mathrm{W} /(\mathrm{m} \cdot \mathrm{K}))$ & $\mathrm{e}\left(\mathrm{W} s^{1 / 2} \mathrm{~cm}^{-2} \mathrm{~K}^{-1}\right)$ \\
\hline $5 \mathrm{GPa} / 1200^{\circ} \mathrm{C} / 1$ minute & $0.340 \pm 0.005$ & $1.00 \pm 0.039$ & $34.0 \pm 0.040$ & $0.58 \pm 0.050$ \\
$5 \mathrm{GPa} / 1200^{\circ} \mathrm{C} / 2$ minute & $0.380 \pm 0.023$ & $1.00 \pm 0.042$ & $38.0 \pm 0.050$ & $0.62 \pm 0.061$ \\
$5 \mathrm{GPa} / 1300^{\circ} \mathrm{C} / 1$ minute & $0.270 \pm 0.046$ & $1.00 \pm 0.082$ & $27.0 \pm 0.094$ & $0.52 \pm 0.107$ \\
$5 \mathrm{GPa} / 1300^{\circ} \mathrm{C} / 2$ minutes & $0.250 \pm 0.013$ & $0.83 \pm 0.020$ & $20.7 \pm 0.020$ & $0.41 \pm 0.020$ \\
$5 \mathrm{GPa} / 1400^{\circ} \mathrm{C} / 1$ minute & $0.370 \pm 0.030$ & $1.30 \pm 0.080$ & $48.1 \pm 0.115$ & $0.79 \pm 0.156$ \\
$5 \mathrm{GPa} / 1400^{\circ} \mathrm{C} / 2$ minutes & $0.400 \pm 0.006$ & $1.00 \pm 0.041$ & $40.0 \pm 0.043$ & $0.63 \pm 0.058$ \\
\hline
\end{tabular}

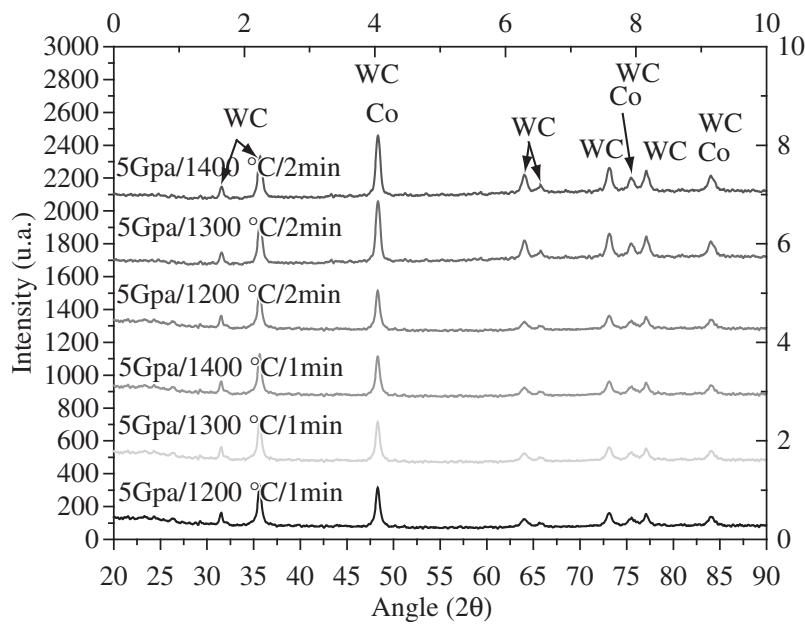

Figure 2. X ray diffractogram for the HPHT sintered hardmetals.

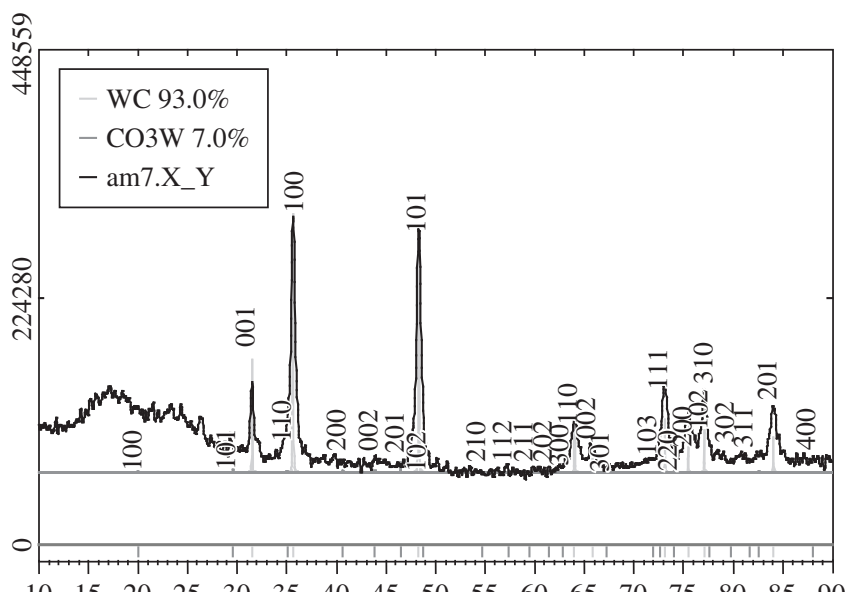

$\begin{array}{lllllllllllllllll}10 & 15 & 20 & 25 & 30 & 35 & 40 & 45 & 50 & 55 & 60 & 65 & 70 & 75 & 80 & 85 & 90\end{array}$

Figure 3. Rietveld Analysis for the $5 \mathrm{GPa} / 1200{ }^{\circ} \mathrm{C} / 1$ minute sample.

In this case, it is desirable that, within the thermal diffusivity $(\alpha)$, the thermal conductivity $(\mathrm{k})$ could also have higher values, because the hard metal works in extreme stress situations, moreover, it is really important that the material reaches in a faster way its thermal balance, so increasing the useful life.

A possible justification for lower values is that in the conventional sintering route, due to the long time that is necessary for firing process, metallic phases appear $\left(\mathrm{W}_{3} \mathrm{Co}_{3} \mathrm{C}, \mathrm{Co}_{6} \mathrm{~W}_{6} \mathrm{C}\right)$, which do not occur for sintering at the HPHT method. Another important factor for the low values of thermal properties is due to the not good homogeneity of the Co mixture. Although our samples present Co addition, there is phonons contribution from the phase WC heat transport. It is neces-

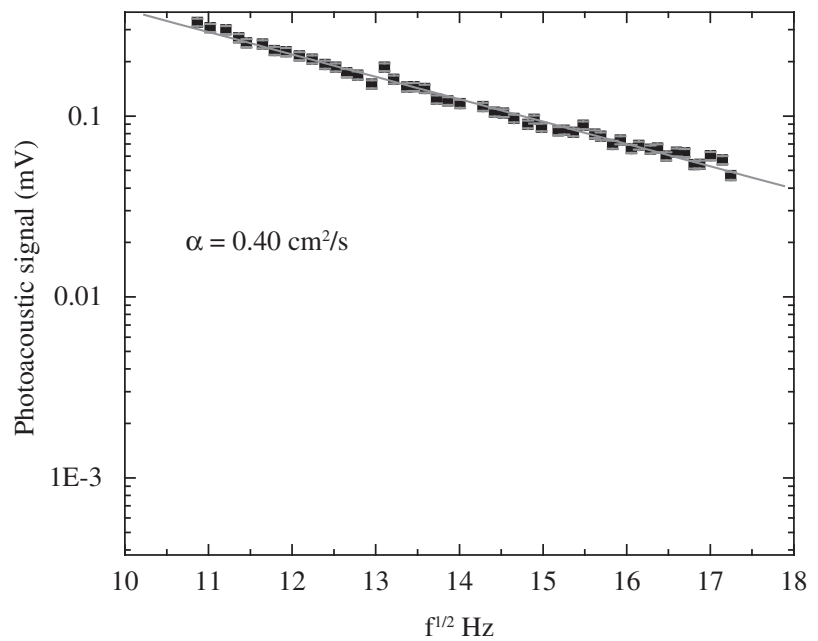

Figure 4. Thermal diffusivity of the $5 \mathrm{GPa} / 1400{ }^{\circ} \mathrm{C} / 2$ minutes HPHT sintered hardmetal.

sary a good crystal homogeneity for a good thermal flow, because phonons transport heat along the crystalline structure. As our HPHT samples present coalescence, porosity, phase transitions, etc, therefore phonons are easily spread out.

The samples $5 \mathrm{GPa} / 1300{ }^{\circ} \mathrm{C} / 1$ minute and $5 \mathrm{GPa} / 1300{ }^{\circ} \mathrm{C} / 2 \mathrm{~min}$ utes presented lower values of thermal properties due to their microstructure, which do not present a good homogeneity of the WC/Co mixture, during the whole production process. Figure 5 shows the microstructure of the sintered body $5 \mathrm{GPa} / 1300{ }^{\circ} \mathrm{C} / 2$ minutes, where great cobalt lakes and a not homogeneous distribution of the $\mathrm{Co}$ binder are shown.

The samples sintered in 1200 and $1400{ }^{\circ} \mathrm{C}$ presented greater thermal property values. In Figures 6 and 7 we can note the microstructure of $5 \mathrm{GPa} / 1200{ }^{\circ} \mathrm{C} / 1$ minute and $5 \mathrm{GPa} / 1400{ }^{\circ} \mathrm{C} / 2$ minutes samples. The typical hardmetal microstructure can be observed, with the grain growth of some particles of WC (white), porosity (black), and cobalt distribution (dark gray). A more homogeneous microstructure in Figure 7 is observed, which presents a better cobalt distribution and presents Co lakes of the order of 5 to $15 \mu \mathrm{m}$, while Figure 6 shows Co lakes of the order of 10 to $25 \mu \mathrm{m}$. The presence of a slight gray phase is observed in Figure 7 (with form of spots), which are uniformly distributed. We attribute to the $\mathrm{Co}_{3} \mathrm{~W}$ phase, identified in Figure 2. The thermal energy absorption (specific heat capacity) is lower among the samples due to a not good distribution of the metal binder. Figure 8 shows a typical curve of specific heat capacity measurements in this case $5 \mathrm{GPa} / 1400{ }^{\circ} \mathrm{C} / 2$ minutes sample.

The thermal effusivity was determined by $\mathrm{e}=\sqrt{\mathrm{kC}}$, which is directly influenced by the thermal conductivity and specific heat capacity. Probably, commercial hardmetals present very higher effusivity in relation to our samples. But, unfortunately, nothing can be stated, 


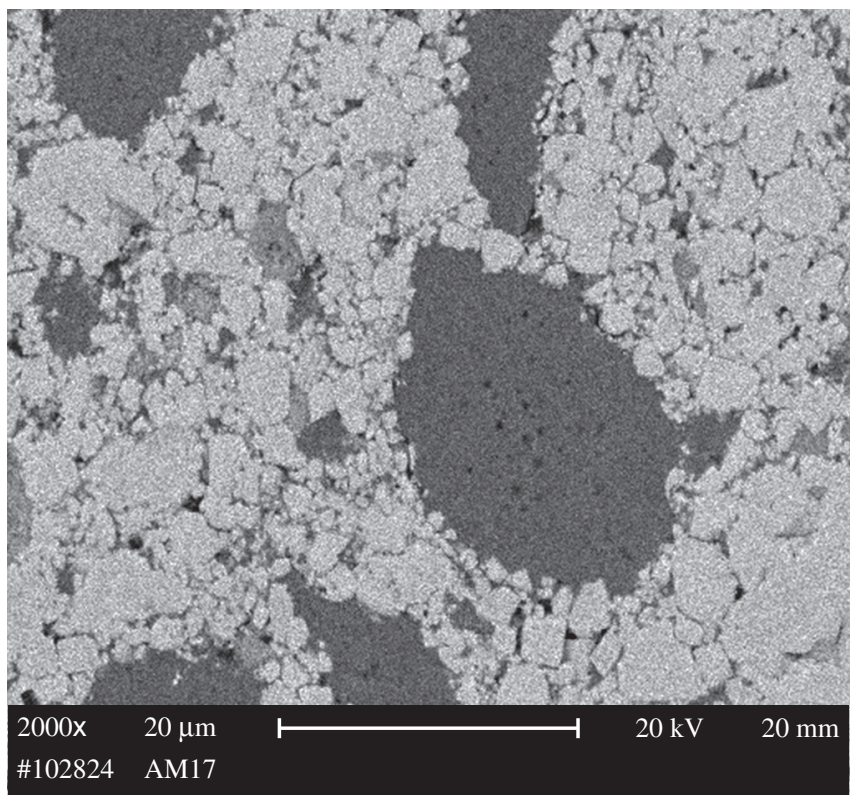

Figure 5. Microstructure of $5 \mathrm{GPa} / 1300^{\circ} \mathrm{C} / 2$ minutes sintered body.

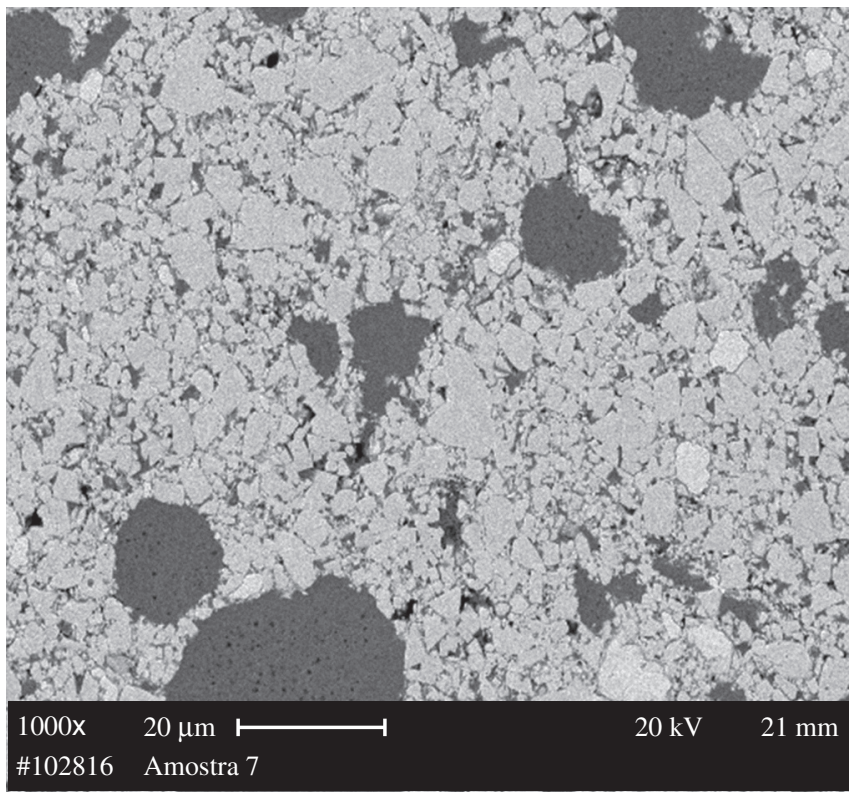

Figure 6. Microestruture of $5 \mathrm{GPa} / 1200^{\circ} \mathrm{C} / 1$ minute sintered body.

because no references were found for comparisons. We intend that these data can play an important role for this kind of material.

\section{Conclusions}

The goal of this exploratory work was reached. The open Photoacoustic cell method is very satisfactory and readily provides thermal properties measurements for hardmetals. The metallic phases $\left(\mathrm{W}_{3} \mathrm{Co}_{3} \mathrm{C}, \mathrm{Co}_{6} \mathrm{~W}_{6} \mathrm{C}\right.$ ) occur, normally to the conventional route, while in the HPHT process there is not enough time to produce these phases. The specific heat capacity presented lower values due to the components distribution characteristics. The cobalt binder did not disperse homogeneously in the samples, originating large Co lakes. On the other hand the thermal diffusivity values are quite realistic to the commercial hardmetals. We can conclude that is necessary more attention to the preparation sample process, mainly in the components

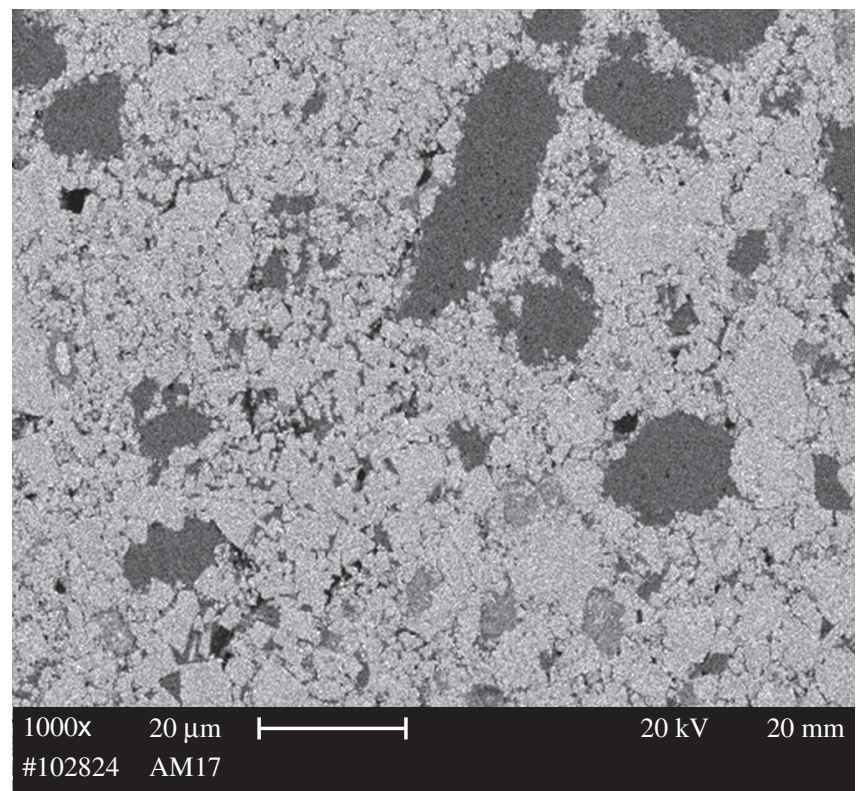

Figure 7. Microstructure of $5 \mathrm{GPa} / 1400{ }^{\circ} \mathrm{C} / 2$ minutes sintered body.

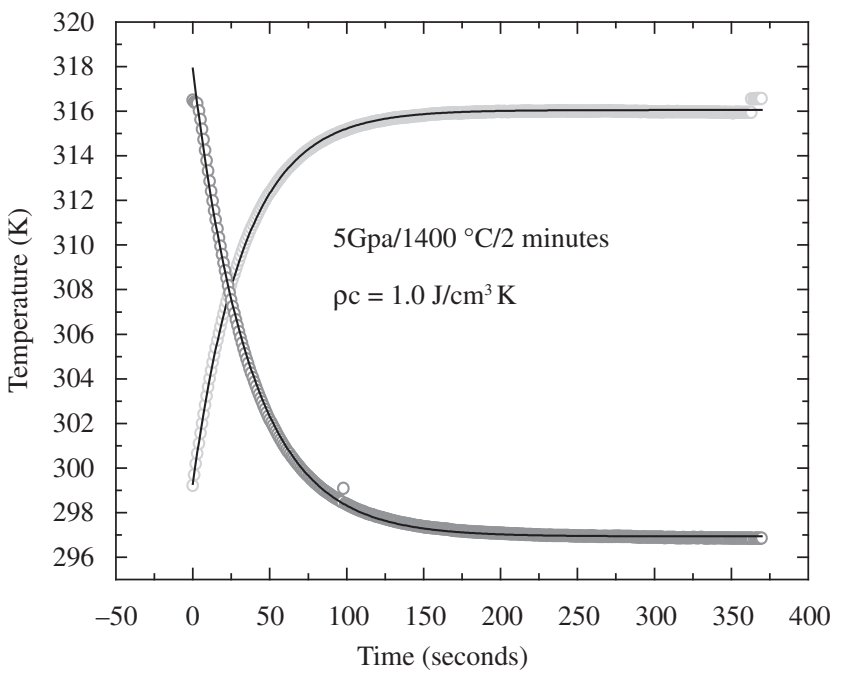

Figure 8. Specific Heat Capacity of the $5 \mathrm{GPa} / 1400{ }^{\circ} \mathrm{C} / 2$ minutes HPHT sintered hardmetal.

mixture phase. The time of the WC--Co mixture should not have been sufficient for a good cobalt distribution in the sample, which harmed the results of some thermal properties. For the first time, effusivity values were determined in relation to these materials.

\section{Acknowledments}

We would like to thank UENF/FAPERJ for the financial support.

\section{References}

1. Bell AG. Upon the Production of Sound by Radiant Energy. Philosophical Magazine. 1881; 11: 510-529.

2. Vargas H, Miranda LCM. Photothermal techniques applied to thermophysical properties measurements. Rewiew of Scientific Instruments. 2003; 74(1): 794-799.

3. Allibert CH. Sintering features of cemented carbides WC-Co processed from fine powders. International Journal of Refractory Metals and Hard Materials. 2001; 19(1): 53-61. 
4. Faria Jr RT, Filgueira M, Esquef IA, Machado FAL, Rodrigues MF, Bobrovnitchii GS, Vargas H. Thermal characterization of sintered hardmetal. Journal of Physique IV. 2005; 125(6): 237-239.

5. Kny E, Neumann W. EinfluBgroBen auf Temperatur - und Warmeleitfahigkeit von WC-Co Hartmetallen. High Temperatures-High Pressures. 1985; 17: 179-189.

6. Faria Jr RT, Rodrigues MF, Esquef IA, Vargas H, Filgueira M. On the thermal characterization of a HPHT sintered WC- $15 \%$ wt Co hardmetal alloy. International Journal of Refractory Metals and Hard Materials. 2005; 23(2): 115-118.

7. Osipov O, Bobrovnitchii G, Filgueira M. Uma Contribuição ao Estudo da Sinterização Sólida do Diamante. Cerâmica. 2003; 49(311): 151-157.

8. Raveendranath K, Ravi J, Jayalekshmi S, Rasheed TMA, Nair KPR Thermal diffusivity measurement on $\mathrm{LiMn}_{2} \mathrm{O}_{4}$ and its de-lithiated form $\left(\lambda-\mathrm{MnO}_{2}\right)$ using photoacoustic technique. Materials Science and Engineering B. 2006; 131(1-3): 210-215.

9. López JAB, Juarez GC, Fonseca MRJ, Sinencio FS. Measurements of thermal effusivity of liquids using a conventional photoacoustic cell. Review of Scientific Instruments. 1999; 70(4): 2069-2071.

10. Vargas H, Miranda LCM. Photoacoustic and related Photothermal techniques. Physics Reports. 1988; 161(2): 43-101.

11. Bribiesca S, Equihua R, Villaseñor L. Photoacoustic Thermal Characterization of Electrical porcelains: Effect of Alumina Additions on thermal Diffusivity and Elastic Constants. Journal of the European Ceramic Society. 1999; 19(11): 1979-1985.

12. Contreras ME, Serrato J, Zarate J. Photoacoustic Thermal Characterization of Lime-Partially Stabilized Zirconia. Journal of American Ceramics Society. 1997; 80(1): 245-249.
13. López JA, Limon JMY, Gil JJA, Vargas H, Silva MD, Miranda LCM. Photoacoustic thermal characterization of wood. Forest Products Journal. 1996; 46(4): 84-89.

14. Mansanares AM, Bento AC, Vargas H, Leite NF, Miranda LCM. Photoacoustic measurement of the thermal properties of two-layer systems. Physical Review B. 1990; 42(7): 4477-4486.

15. Calderon A, Gil JJA, Gurevich GY, Orea AC, Delgadilho I, Vargas H, Miranda LCM. Photothermal Characterization of Electrochemical Etching Processed n-Type Porous Silicon. Physical Review Letters. 1997; 79(25): 5022-5025.

16. Cella N, Vargas H, Galembeck E, Galembeck F, Miranda LCM. Photoacoustic monitoring of cross linking reactions in low-density polyethylene. Journal Polymers Scientific Letters. 1989; 27(9): 313-320.

17. Alexandre J, Saboya F, Marques BC, Ribeiro MLP, Salles C, da Silva MG, Sthel MS, Auler LT, Vargas H. Photoacoustic thermal characterization of kaolinite clays. The Analyst. 1999; 124: 1209-1214.

18. Rosencwaig A, Gersho A. Theory of the photoacoustic effect with solids. Journal of Applied Physics. 1976; 47(1): 64-69.

19. Miranzo P, Osendi MI, Garcia E, Fernandes AJS, Silva VA, Costa FM, Silva RF. Thermal conductivity enhancement in cutting tools by chemical vapor deposition diamond coating. Diamond and Related Materials. 2002; 11(3-6): 703-707.

20. Lauwers B, Liu W, Eeraerts W. Influence of the composition of Wc-Based Cermets on the manufacturability by Wire-EDM. [Personal Communication]. Leuven, Belgium: Katholieke Universiteit; 2000. 
